\title{
BLOOD INDICES IN COWS WITH DIFFERENT PHYSIOLOGICAL AND PATHOLOGICAL STATES OF THE OVARIES
}

\author{
S. Kornyat, M. Sharan, D. Ostapiv, A. Korbetskyy, I. Jaremchuk, O. Andrushko \\ m_sharan@ukr.net
}

Institute of Animal Biology NAAS,

38 V. Stusa str., Lviv 79034, Ukraine

The purpose of this work was to study the functional morphology of cow reproduction system at such ovary's pathologies as follicular cysts, luteal cysts, persistent corpus luteum, hypofunction of ovaries and during normal cycle (follicular or luteal phases). Blood samples were taken for biochemical studies during the diagnosis making process. In blood samples the activity of alanine and aspartate aminotransferase (ALT and AST); state of the antioxidant system: diene conjugates, the activity of superoxide dismutase (SOD), glutathione peroxidase (GP), hemoglobin content; progesterone and estradiol concentration were determined. The data received was statistically processed with Office Excel (Microsoft, USA). In cows with persistent corpus luteum high progesterone level $(7.6 \pm 1.2 \mathrm{ng} / \mathrm{ml}$ ) was observed while estradiol concentration was low $(2.3 \pm 0.5 \mathrm{pg} / \mathrm{ml})$ compared to the hormone levels in cows with available corpus luteum during normal ovarian cycle ( $P<0.01$ and $P<0.05$, respectively). In cows with follicular cysts the concentration of progesterone in blood was $1.5 \pm 0.5 \mathrm{ng} / \mathrm{ml}$, which was 5-8 times less compared to the result for luteal cysts. At the same time, the concentration of estradiol was the highest $(26.3 \pm 4.0 \mathrm{pg} / \mathrm{ml})$, which was 7.7-11.4 times higher than in cows with persistent corpus luteum and luteal cysts. Compared to the animals with follicles on the ovaries, the level of estradiol was significantly higher $(P<0.01)$. The lowest concentrations of steroid hormones were detected in cows with ovarian hypofunction. The difference in progesterone level was significant in the group of cows with corpus luteum of the sexual cycle $(P<0.001)$, while the difference in estradiol level was significant in the group of animals with available corpus luteum $(P<0.001)$ and follicle $(P<0.001)$. In cows with ovarian hypofunction the lowest level of the studied parameters was observed which were significantly different from the cows with corpus luteum of sexual cycle for diene conjugates $(P<0.001)$, superoxide dismutase $(P<0.05)$, glutathione peroxidase $(P<0.01)$, hemoglobin $(P<0.05)$, alanine aminotransferase $(P<0.01)$ and aspartate aminotransferase $(P<0.05)$. Comparing the group of cows with follicles in the ovaries, there were observed significant differences in the group of cows with hypofunction of the ovaries according to the indices such as diene conjugates $(P<0.001)$, glutathione peroxidase $(P<0.001)$, hemoglobin $(P<0.05)$, alanine aminotransferase $(P<0.01)$. When the follicular cysts in cows were present, the level of diene conjugates $(P<0.05)$ and glutathione peroxidase $(P<0.01)$ were significantly lower than in cows with follicles that developed during the normal sexual cycle. Changes of cow's blood biochemical parameters in normal and pathological conditions of the ovaries (corpus luteum, follicle, persistent corpus luteum, hypofunction, follicular and luteal cysts) were established. In order to make a clear diagnosis of the functional state of the cow ovaries, complex examination should be carried out that would include rectal and ultrasound examination of the cows together with determination of steroid hormones and individual blood biochemical parameters.

\section{Keywords: COWS, OVARIES, BLOOD, SEXUAL CYCLE, STEROID HORMONES}

\section{ПОКАЗНИКИ КРОВІ КОРІВ ЗА РІЗНИХ ФІЗІОЛОГІЧНИХ ТА ПАТОЛОГІЧНИХ СТАНІВ ЯЕЧНИКІВ}

\author{
С. Корнят, М. Шаран, Д. Остапів, А. Корбецький, І. Яремчук, О. Андрушко \\ m_sharan@ukr.net
}

Інститут біології тварин НААН,

вул. В. Стуса, 38, м. Львів, 79034, Україна

Метою роботи було вивчити функиіональні зміни системи відтворення корів за таких патологій яєчників, як фолікулярна кіста, лютеїнові кісти, персистуюче жовте тіло, гіпофункиія яєчників та під час фізіологічного статевого ииклу (фолікулярна або лютеїнова фази). Проби крові для біохімічних досліджень брали у процесі постановки діагнозу. Узразках крові визначали: активність аланін- та аспартатамінотрансферази (ALTта AST); стан антиоксидантної системи: дієнові кон 'югати, активність супероксиддисмутази (СОД), глутатіонпероксидази (ГП), вміст гемоглобіну; кониентрацію прогестерону та естрадіолу. Отримані дані були статистично оброблені Office Excel (Microsoft, США). У корів з персистуючим жовтим тілом спостері-

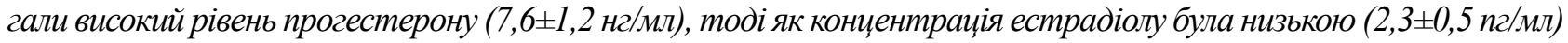


порівняно з рівнем гормону у корів із наявним жовтим тілом під час нормального изиклуяєчників $(P<0,01$ i $P<0,05$

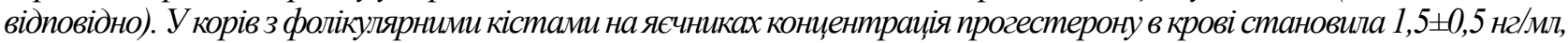
щзо в 5-8 разів менше порівняно з результатом за лютеӥнових кіст. Водночас концентрація естрадіолу була

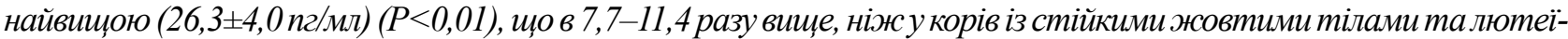
новими кістами. Найнижчі концентрації стероїдних гормонів були виявлені у корів з гіпофункцією яєчників. Різниця в рівні прогестерону була значною порівняно з групою корів із жовтим тілом статевого циклу $(P<0,001)$, тоді як різниця в рівні естрадіолу була вірогідною $(P<0,001)$ порівняно з групою тварин з наявним жовтим тілом та фолікулом $(P<0,001)$ на яєчнику. У корів з гіпофункиією яєчників спостерігали найнижчий рівень досліджуваних показників, який суттєво відрізнявся від корів з жовтим тілом статевого ичиклу для дієнових кон'югатів $(P<0,001)$, СОД $(P<0,05)$, ПП $(P<0,01)$, гемоглобіну $(P<0,05)$, ALT $(P<0,01)$ ma AST $(P<0,05)$. Порівнюючи групу корів з фолікулами в яєчниках, спостерігали значні відмінності від групи корів з гіпофункцією яєчників за такими показниками, як дієнові кон'югати ( $P<0,001)$, ГП $(P<0,001)$, гемоглобін $(P<0,05)$, ALT $(P<0,01)$. Рівень дієнових кон 'югатів $(P<0,05)$ та активність ГП $(P<0,01)$ за наявності у корів фолікулярних кіст були значно нижсими, ніж у корів з фолікулами, які розвинулися під час нормального статевого циклу. Отжсе, встановлено зміни біохімічних показників крові корів за фізіологічних і патологічних станів яєчників (жовте тіло, фолікул, персистуюче жовте тіло, гіпофункиія, фолікулярні та лютеїнові кісти). Для постановки чіткого діагнозу функціонального стану яєчників корів необхідно провести комплексне обстеження: ректальне та ультразвукове дослідження корів разом із визначенням стероїдни гормонів та окремих біохімічних показників крові.

\title{
Ключові слова: КОРОВИ, ЯЄЧНИКИ, КРОВ, СТАТЕВИЙ ЦИКЛ, СТЕРОЇДНІ ГОРМОНИ
}

\section{ПОКАЗАТЕЛИ КРОВИ КОРОВ ПРИ РАЗЛИЧНЫХ ФИЗИОЛОГИЧЕСКИХ И ПАТОЛОГИЧЕСКИХ СОСТОЯНИЯХ ЯИЧНИКОВ}

\author{
С. Корнят, М. Шаран, Д. Остапив, А. Корбецкий, И. Яремчук, А. Андрушко \\ m_sharan@ukr.net
}

Институт биологии животных НААН, ул. В. Стуса, 38, Львов, 79034, Украина

Целью работы было изучить функциональные изменения системы воспроизводства коров при таких патологиях яичников, как фолликулярная киста, лютеиновая киста, персистирующее желтое тело, гипофункция яичников и в период физиологического полового циикла (фолликулярная или лютеиновая фазы). Пробы крови для биохимических исследований брали в прочессе постановки диагноза. В образиах крови определяли: активность аланин- и аспартатаминотрансферазы (ALT и AST), состояние антиоксидантной системь: диеновые конъюгаты, активность супероксиддисмутазы (СОД), глутатионпероксидазы (ГП), содержание гемоглобина; концентрация прогестерона и эстрадиола. Полученные данные статистически обработаны Office Excel (Microsoft, США). У коров с персистируюшим желтым телом наблюдался высо-

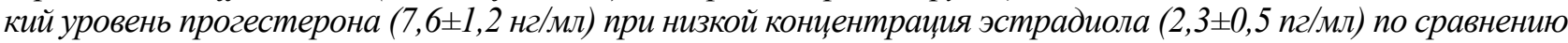
с уровнем гормона у коров с имеющимся желтылм телом во время физиологического ичикла яичников (P<0,01 и $P<0,05$ соответственно). У коров с фолликулярныли кистами на яичниках концентраџия прогестерона в крови составляла 1,5 \pm 0,5 нг/мл, что в 5-8 раз меньше по сравнению с результатом при лютеиновой кисте.

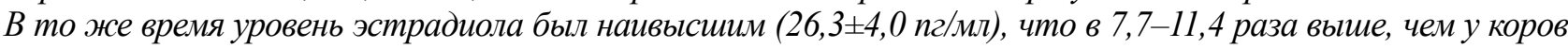
с персистирующими желтыми телами и лютеиновыми кистами. По сравнению с животными, у которых есть фолликульл на яичниках, уровень эстрадиола был значительно выше $(P<0,01)$. Самыле низкие кониентрачии стероидных гормонов обнаружены у коров с гипофункцией яичников: достоверная разница уровня прогестерона в сравнении с группой коров с желтыл телом полового цикла $(P<0,001)$, отмечена достоверная разница в уровне эстрадиола в сравнении с коровами с желтыл телом $(P<0,001)$ и фолликулом $(P<0,001)$ на яичнике. У коров с гипофункцией яичнков наблюдался самый низкий уровень исследуемых показателей и существенно отличался от коров с имеюшимся на яичнике желтым телом полового цикла для диеновых конъюгатов $(P<0,001)$, СОД $(P<0,05)$, ГП $(P<0,01)$, гемоглобина $(P<0,05), A L T(P<0,01)$ u $A S T(P<0,05)$. Сравнивая группу коров с фолликулами в яичниках, наблюдали значительные отличия от коров с гипофункцией яичников по таким показателям: диеновые конъюгаты $(P<0,001)$, ГП $(P<0,001)$, гемоглобин $(P<0,05)$, ALT $(P<0,01)$. Уровень диеновых конъюгатов $(P<0,05)$ и активность ГП $(P<0,01)$ были значительно ниюе у коров с фолликулярньли кистами, чем у коров с фолликулами, развивиимися во время нормального полового ичила. Установлено изменение биохимических показателей крови коров при физиологических и патологических состояниях яичников (желтое тело, фолликул, персистирующее желтое тело, гипофункция, фолликулярные и лютеиновые кисты). Для постановки точного диагноза функционального состояния яичников 
коров необходимо провести комплексное обследование: ректальное и ультразвуковое исследование коров вместе с определением стероидных гормонов и отдельных биохимических показателей крови.

\section{Ключевые слова: КОРОВЫ, ЯИЧНИКИ, КРОВЬ, ПОЛОВОЙ ЦИКЛ, СТЕРОИДНЫЕ ГОРМОНЫ}

Estimation of functional morphology of farm animal's reproductive organs in normal and pathological states is one of the most complex and actual problem in biology and veterinary medicine. Great interest in it is not limited to purely theoretical considerations, since achievements in this field are directly related to the cardinal challenges in animal reproduction that find direct and effective application in practice $[8,9,13]$.

The lack of information related to morphology and function of cow's ovaries in normal and pathological states does not allow to effectively solve a number of modern tasks in practice such as embryo transfer, estrus synchronization, prevention of symptomatic infertility, differential diagnosis of diseases of reproductive organs, their prevention and treatment, development of luteolytic drugs [9].

Often, the causes of infertility in cows are ovarian hypofunction, persistent corpus luteum and ovarian cysts. Mechanism of these disorders is mainly hormonal disorders of sexual cycle regulation, associated with nutritional, ethological and man-made factors $[3,7]$. However, the serious barrier to intensive livestock management is symptomatic infertility, which in most cases is due to the functional ovarian disorders [3].

Functional ovarian disorder such as ovarian cysts is of great scientific and practical interest since they are the cause of infertility in 1.7-60\% of gynecologically ill cows $[2,4,12]$. Cystic ovarian degeneration is, in most cases, the cause of infertility of young, highly productive cows $[5,11]$, which have not fully realized their breeding and productive potential.

According to many researchers, persistent corpus luteum is one of the causes of symptomatic infertility. The currently existing diagnostic methods, based on clinical and, primarily, rectal examination, do not reflect the entire complexity of pathological processes occurring in the ovarian glands and the uterus in this pathology. Mechanisms of luteinization and luteolysis are not completely elucidated. Almost no data has been shown regarding other types of luteal ovarian structures and their role in pathology of ovarian glands also has not been ascertained $[1,6]$.

The lack of information related to the function of this endocrine gland does not allow to effectively solve a number of modern tasks used in practice such as embryo transfer, heat synchronization, prophylaxis of symptomatic infertility, differential diagnosis of diseases in reproductive organs, their prevention and treatment, development of luteolithic drugs.

\section{Materials and methods}

The study was carried out at "Imeni Volovikova" LLC (Rivne region, Ukraine) on cows of Ukrainian Black Pied breed at the age of 3-7 years with productivity of 5-6 thousand $\mathrm{kg}$ of milk per lactation. Six groups of 5 cows in each were selected and formed with each of the following functional ovarian states: follicular cyst, luteal cysts, persistent corpus luteum, ovarian hypofunction and normal state (follicular or luteal phase of the cycle). Diseases anamnesis collection, clinical examination of animals with rectal diagnosis of the ovarian functional state were carried out.

During diagnosics blood samples were taken for biochemical studies. In blood the activity of alanine and aspartate aminotransferase (ALT and AST) by the method of K. G. Kapetanaki (1962); state of the antioxidant system: diene conjugates by the method of I. D. Stalna (1977), the activity of superoxide dismutase (SOD) by E. E. Dubinin et al. (1988), glutathione peroxidase (GP) V. M. Moin (1986), hemoglobin content by the method of Drabkin; the concentration of progesterone and estradiol by the ELISA method [10] were determined. The collected data was statistically processed with Office Excel (Microsoft, USA).

\section{Results and discussion}

In our studies, first of all we took into account the clinical manifestations of ovarian diseases and supplemented by anamnesis data. In particu- 
lar, the ovarian hypofunction was manifested by anaphrodisia or suppressed and irregular sexual cycles. Follicular cysts increase sexual excitation, sexual cycles were irregular, often shortened, prolonged sexual heat and nymphomania. Luteal cysts and persistent corpus luteum were accompanied by anaphrodisia or anovulatory sexual cycles.

Analyzing the concentration of steroid hormones in blood plasma of cows with different functional state of the ovaries, in some cases, there were significant differences between the groups of animals (table 1). In cows with persistent corpus luteum high progesterone level $(7.6 \pm 1.2 \mathrm{ng} / \mathrm{ml})$ was observed while estradiol concentration was low $(2.3 \pm 0.5 \mathrm{pg} / \mathrm{ml})$ compared to the hormone levels in cows with available corpus luteum during normal ovarian cycle ( $\mathrm{P}<0.01$ and $\mathrm{P}<0.05$, respectively).

In cows with follicular cysts the concentration of progesterone in blood was $1.5 \pm 0.5 \mathrm{ng} / \mathrm{ml}$, which is 5-8 times less compared to the result for luteal cysts. At the same time, the concentration of estradiol was the highest $(26.3 \pm 4.0 \mathrm{pg} / \mathrm{ml})$, which is 7.7-11.4 times higher than in cows with persistent

Table 1

Concentration of steroid hormones in blood plasma of cows $(M \pm m, n=5)$

\begin{tabular}{|l|c|c|}
\hline \multicolumn{1}{|c|}{$\begin{array}{c}\text { Functional state } \\
\text { of ovaries }\end{array}$} & $\begin{array}{c}\text { Progesterone, } \\
\mathrm{ng} / \mathrm{ml}\end{array}$ & $\begin{array}{c}\text { Estradiol, } \\
\mathrm{pg} / \mathrm{ml}\end{array}$ \\
\hline Persistent corpus luteum & $7.6 \pm 1.2 * *$ & $2.3 \pm 0.5^{*}$ \\
\hline Luteal cyst & $12.2 \pm 5.5$ & $3.4 \pm 1.5$ \\
\hline Follicular cyst & $1.5 \pm 0.5$ & $26.3 \pm 4.0 * *$ \\
\hline Hypofunction of ovary & $\begin{array}{c}1.2 \pm 0.05 \\
(1) * * *\end{array}$ & $\begin{array}{c}2.2 \pm 0.05 \\
(1) * * *,(2) * * *\end{array}$ \\
\hline Corpus luteum & $2.6 \pm 0.14$ & $0.9 \pm 0.12$ \\
\hline Follicle & $1.2 \pm 0.22$ & $8.6 \pm 0.95$ \\
\hline
\end{tabular}

Note: in this and subsequent tables, the difference in groups with persistent corpus luteum, luteal cyst and hypofunction of the ovaries (1) compared with group of animals in which the physiological corpus luteum was found on the ovary, and in groups with follicular cysts of the ovary and ovarian hypofunction (2) compared to the group in cows the physiological follicle is found to be statically significant: * $-\mathrm{P}<0.05 ; * *-\mathrm{P}<0.01 ; * * *-\mathrm{P}<0.001$. corpus luteum and luteal cysts. Compared to the animals with follicles on the ovaries, the level of estradiol was significantly higher $(\mathrm{P}<0.01)$. The lowest concentrations of steroid hormones were detected in cows with hypofunction of the ovaries. The difference in progesterone level was significant in the group of cows with corpus luteum of the sexual cycle $(\mathrm{P}<0.001)$, while the difference in estradiol level was significant in the group of animals with available corpus luteum $(\mathrm{P}<0.001)$ and follicle $(\mathrm{P}<0.001)$.

Analyzing the state of the other blood indices in cows, certain changes were observed in different functional conditions of the ovaries (table 2). Thus, the content of diene conjugates in the blood of cows with corpus luteum and follicle of the ovary was twice as high as in cows with hypofunction of the ovarian glands. Similarly, the activity of SOD and GP was higher in the normal state of ovaries by 36.0 and $32.0 \%$, and by 24.6 and $25.2 \%$ respectively compared to the cows with presence ovarian hypofunction. In particular, in cows with ovarian hypofunction, according to the studied parameters, the lowest level of antioxidant defense was observed and was significantly different from the cows with corpus luteum of sexual cycle for diene conjugates $(\mathrm{P}<0.001)$, superoxide dismutase $(\mathrm{P}<0.05)$, glutathione peroxidase $(\mathrm{P}<0.01)$, hemoglobin $(\mathrm{P}<0.05)$, alanine aminotransferase $(\mathrm{P}<0.01)$ and aspartate aminotransferase $(\mathrm{P}<0.05)$. Compared to the group of cows with follicles in the ovaries, there were observed significant differences in the group of cows with hypofunction of the ovaries according to the indices such as diene conjugates $(\mathrm{P}<0.001)$, glutathione peroxidase $(\mathrm{P}<0.001)$, hemoglobin $(\mathrm{P}<0.05)$, alanine aminotransferase $(\mathrm{P}<0.01)$.

The presence of such ovarian pathologies as persistent corpus luteum, follicular and luteal cysts was accompanied by a slightly lower level of all investigated in this studied parameters than in normal

Indices of blood in cows $(\mathrm{M} \pm \mathrm{m}, \mathbf{n}=\mathbf{5})$

Table 2

\begin{tabular}{|c|c|c|c|c|c|c|}
\hline $\begin{array}{c}\text { Functional } \\
\text { ovarian state }\end{array}$ & $\begin{array}{c}\text { Diene conjugates, } \\
\mathrm{mkmol} / \mathrm{l}\end{array}$ & $\begin{array}{l}\text { SOD, \% bloc. } \\
\text { reac. } / 1 \text { g. Hb }\end{array}$ & $\begin{array}{c}\mathrm{GP}, \\
\mathrm{mkmol} / \mathrm{min} / 1 \mathrm{~g} \mathrm{Hb}\end{array}$ & $\begin{array}{l}\text { Hemoglobin, } \\
\mathrm{g} / \mathrm{l}\end{array}$ & $\begin{array}{l}\text { ALT, } \\
\text { ncat/l }\end{array}$ & $\begin{array}{l}\text { AST, } \\
\text { ncat/l }\end{array}$ \\
\hline Persistent corpus luteum & $4.22 \pm 0.44$ & $0.31 \pm 0.02$ & $401.2 \pm 10.64$ & $117.6 \pm 8.03$ & $294.7 \pm 23.45$ & $383.6 \pm 33.45$ \\
\hline Luteal cyst & $3.84 \pm 0.35^{*}$ & $0.28 \pm 0.02$ & $387.3 \pm 11.87$ & $112.3 \pm 8.67$ & $255.8 \pm 26.32$ & $378.1 \pm 29.33$ \\
\hline Follicular & 3.91 & $0.27 \pm 0.03$ & $352.9 \pm 7.65 * *$ & $114.9 \pm 6.18$ & $300.2 \pm 28.94$ & $461.5 \pm 32.18$ \\
\hline Hypofunction of ovary & $\begin{array}{c}2.37 \pm 0.32 \\
(1) * * *(2) * * *\end{array}$ & $\begin{array}{l}0.25 \pm 0.02 \\
\text { (1)* }\end{array}$ & $\begin{array}{c}323.9 \pm 9.12^{(1) * *} \\
\text { (2)*** }\end{array}$ & $\begin{array}{l}97.2 \pm 3.47 \\
\text { (1)* (2)* }\end{array}$ & $\begin{array}{c}161.2 \pm 16.23 \\
(1) * * \text { (2)** }\end{array}$ & $\begin{array}{c}322.5 \pm 26.61 \\
\text { (1)* }\end{array}$ \\
\hline Corpus luteum & & $0.34 \pm 0.03$ & $403.5 \pm 15.44$ & $125.6 \pm 9.77$ & $287.9 \pm 22.45$ & $467.0 \pm 38.27$ \\
\hline Follicle & $5.36 \pm 0.46$ & $0.33 \pm 0.03$ & $405.1 \pm 12.23$ & $124.6 \pm 10.33$ & $283.6 \pm 19.75$ & $411.4 \pm 35.67$ \\
\hline
\end{tabular}


physiological states of ovarian glands. However, they were significantly higher compared to the cows with presence of ovarian hypofunction. In the group of cows with persistent corpus luteum, compared to the group of cows with corpus luteum of sexual cycle, there were no significant differences despite of slightly lower values of all indices except alanine aminotransferase. Comparing cows with luteal ovarian cysts and cows with physiologic corpus luteum, there was also a lower level of all studied indices in this table, but the difference was significant for diene conjugates $(\mathrm{P}<0.05)$. In the presence of follicular cysts in cows, the level of diene conjugates $(\mathrm{P}<0.05)$ and glutathione peroxidase $(\mathrm{P}<0.01)$ were significantly lower than in cows with follicles that developed during the normal sexual cycle.

\section{Conclusions}

Changes in biochemical parameters of cow's blood in normal and pathological conditions of ovaries (corpus luteum, follicle, persistent corpus luteum, hypofunction, follicular and luteal cysts) were established. In the presence of persistent corpus luteum, a high level of progesterone $(7.6 \pm 1.2 \mathrm{ng} / \mathrm{ml})$ was observed whilst some lower estradiol concentrations $(2.3 \pm 0.5 \mathrm{pg} / \mathrm{ml})$ compared to the level of hormone in cows with an available corpus luteum of sexual cycle ( $\mathrm{P}<0.01$ and $\mathrm{P}<0.05$, respectively). In cows with follicular cysts the concentration of estradiol was significantly higher than in animals with ovarian follicles $(\mathrm{P}<0.01)$. The lowest concentrations of steroid hormones were detected in cows with ovarian hypofunction. The difference in progesterone level was significant compared to the group of cows with corpus luteum of sexual cycle $(\mathrm{P}<0.001)$, while the difference in estradiol level was significant compared to the groups of animals with available corpus luteum $(\mathrm{P}<0.001)$ and follicle $(\mathrm{P}<0.001)$. In order to make a clear diagnosis of functional state of the cow's ovaries, complex examination should be carried out that would include rectal and ultrasound examination of cows together with determination of steroid hormones and individual blood biochemical parameters.

\section{Perspectives of the future investigations.}

In this work changes of biochemical parameters of blood of cows at physiological and pathological conditions of ovaries (corpus luteum, follicle, per- sistent corpus luteum, hypofunction of ovaries, follicular and luteal cysts) are established. It is planned to work on a clear diagnosis of the functional status of the ovaries of cows by conducting a comprehensive examination of diseased and healthy animals, which would include rectal examination of the ovaries manually and with the help of an ultrasound scanner together with the determination of steroid hormones and individual biochemical parameters.

1. Bove S. E., Petroff M. G., Nishibori M., Pate J. L. Macrophage migration inhibitory factor in the bovine corpus luteum. Biology of reproduction, 2000, vol. 62, issue 4, pp. 879-885. DOI: 10.1095/ biolreprod62.4.879.

2. Chomaev A. M. Diagnosis and treatment of cow follicular cysts. Reports of RAAS, 1997, vol. 4, pp. 36-37. (in Russian)

3. Dulger H. P. Cystic pathology of the ovaries in cows and the improvement of the methods for its differential diagnosis and therapy. Doctoral thesis, Moscow, 2008, 232 p. (in Russian)

4. Glaz A. V. Features of the functional disorders of the ovaries in cows. Academic records of Grodno Agrarian Institute, 1994, issue 4, 106 p.

5. Mahotkin A. H. The use of hormonal drugs for some functional disorders of the ovaries in cows. Improving the breeding and productive qualities of animals. Interuniversity collection of scientific papers, Kazan, 1995, pp. 95-99. (in Russian)

6. Murphy B. D. Models of luteinization. Biology of reproduction, 2000, vol. 63, issue 1, pp. 2-11. DOI: 10.1095/biolreprod63.1.2.

7. Nikulin A. V. Correction of metabolic and trophic processes in cows with ovarian dysfunction by biological placenta bio-normalizers. Doctoral thesis, Belgorod, 2005, 179 p. (in Russian)

8. Polancev N. I., Podberezny V. V. Veterinary obstetrics and biotechnology animal reproduction. RostovOn-Don, Fenix, 2001, pp. 445-447. (in Russian)

9. Sharipov A. F. Functional morphology of corpus luteum ovarian cows in normal state and with pathologies. Doctoral thesis, Ufa, 2008, 158 p. (in Russian)

10. Vlizlo V. V. (ed.), Fedoruk R. S., Ratych I. B. Laboratory methods of investigation in biology, stock-breeding and veterinary. A reference book. Lviv, Spolom, 2012, 764 p. (in Ukrainian)

11.Zemlanikin V. V. Correction of reproductive function in cows with follicular ovarian cysts. Doctoral thesis, Saratov, 2004, 170 p. (in Russian)

12.Zöldág L., Vetési F., Solti L., Molnár L. A ciklikus sárgatest és a folliculus-luteincysta összehasonlító endokrinológiai és morfológiai tanulmányozása szarvasmarhában. Magyar Allatorvosok Lapja, 1986, vol. 41, issue 6, pp. 343-347. (in Hungarian)

13.Zvereva H. V., Homyn S. P. Gynecological diseases of cows. Kyiv, Urozhay, 1976, 152 p. (in Ukrainian) 